\title{
Mismatch between diagnostic reports and special educational needs classification in a public educational system
}

\author{
Descompasso entre os registros diagnósticos e a classificação de necessidade \\ educacional especial em uma rede municipal de educação
}

Maria Cristina Triguero Veloz Teixeira', Décio Brunoni', Luiz Renato Rodrigues Carreiro', Ana Claudia Braga', Naiara Adorna da Silva ${ }^{1}$, Cristiane Silvestre Paula ${ }^{1}$

\begin{abstract}
Objective: To assess the diagnostic status, the sociodemographic and health profiles for students with special educational needs (SEN) in a public educational system, and to map their use of educational/social services. Methods: The sample comprised 1,202 SEN students from a total of 59,344 students. Results: Only 792 students of the 1,202 had an established diagnosis. The most prevalent SEN condition was intellectual disability. There was a low percentage (29.4\%) of use of specialized educational services or support. It was found that, for some neurodevelopmental disorders, prevalence data suggest an under-reporting in the school system. Conclusion: Results suggest that there is a mismatch between the diagnostic reports and the SEN condition legally recognized according to Brazilian law, in addition to the under-reporting and under specialized service use of students with disabilities.
\end{abstract}

Keywords: diagnosis; child; school; disability.

\section{RESUMO}

Objetivo: Avaliar a situação diagnóstica, o perfil sociodemográfico e de saúde dos alunos com necessidades educacionais especiais (NEE) de uma rede municipal de educação, assim como mapear o uso de serviços educacionais e sociais. Métodos: A amostra foi composta por 1202 alunos com NEE de um total de 59344 alunos. Resultados: Dos 1202 alunos somente 792 tinha diagnóstico estabelecido. A condição de NEE mais prevalente foi a deficiência intelectual. Verificou-se um baixo percentual (29,4\%) de uso de serviços educacionais especializados ou de apoio. Foi constatado que, para alguns transtornos do neurodesenvolvimento, os dados de prevalência parecem indicar uma subnotificação. Conclusão: Os resultados sugerem um descompasso entre os registros diagnósticos e a condição de necessidade educacional especial segundo a legislação brasileira, além disso verificou-se uma subnotificação diagnóstica e baixo uso de serviços especializados entre estudantes com deficiências.

Palavras-chave: diagnóstico; criança; escola; deficiência.

In developed countries, the identification of neurodevelopmental disorders for health interventions, education and psychosocial management is usually done with periodic population screening ${ }^{1,2,3}$. This not only allows the prevalence rates of these disorders to be established, but also helps to clarify genetic and environmental risk factors and, consequently, influence the development of public health and education policies.

In Brazil, the National Policy for Inclusive Education began to be outlined at the beginning of 2000. A government decree, 6571/2008, was issued giving legal support to the policy. The decree has been amended over time, with changes being made to regulations, technical notes and resolutions. The latest document outlining all the policy details is called, "Guidelines for the Implementation of Special Education Policy in Relation to Inclusive Education" published by the Ministry of Education. Currently, there are seven conditions supported by this policy: intellectual, visual, hearing, physical, multiple disabilities/impairment and autism spectrum disorders, and high skills ${ }^{4}$. To be entitled to an education plan specifically structured to their needs, students with

${ }^{1}$ Universidade Presbiteriana Mackenzie; Programa de Pós-graduação em Distúrbios do Desenvolvimento; São Paulo SP, Brasil.

Correspondence: Maria Cristina Triguero Veloz Teixeira; Programa de Pós-Graduação em Distúrbios do Desenvolvimento, Mackenzie; Rua da Consolação, 930 / Prédio 28 / $1{ }^{\circ}$ andar; 01302-907 São Paulo SP, Brasil; E-mail: cris@teixeira.org

Conflict of interest: There is no conflict of interest to declare.

Support: CAPES

Received 06 June 2016; Received in final form 25 October 2016; Accepted 03 November 2016. 
special educational needs (SEN) have to be given a diagnosis. However, there are few studies that verify the reliability of the diagnoses of SEN students in Brazil. In addition, Brazilian studies that map the diagnosis, and characterize and describe the educational and health service usage profiles of SEN students are even scarcer.

In any area of health, reliable diagnostics are essential to guide treatment recommendations, identify prevalence rates, and plan educational and mental health service provision ${ }^{5}$. In the specific case of special educational support services, a reliable diagnosis has several advantages for the child or adolescent affected, their families and for the broader society. For example, for an educator it would allow them to develop educational and pedagogical action plans tailored to the typical characteristics of the disorder and to the specificities of the students' to cognitive functioning, behavioral patterns, learning skills and social and adaptive functioning ${ }^{6}$. With regard to the law, a correct and trustworthy diagnosis allows the family and the community to guarantee the rights protected by the current legislation ${ }^{5,7}$.

Diagnostic evaluation of a given population should be done through periodic monitoring, helping to identify vulnerable cases and thus increasing the chances of individuals receiving appropriate treatment according to their needs ${ }^{8}$. Neurodevelopment disorders during childhood need to be monitored from an early age to deliver interventions in line with development indicators.

Taking into account the importance and scarcity of population data on Brazilian students with SEN, this study aimed to examine their diagnostic status, and socio-demographic and health profiles in a public school system.

\section{METHODS}

\section{Participants}

The study sample was based on secondary data from a database produced by the Municipal Secretariat for the Rights of People with Disabilities from a public educational system. This database was designed to record and characterize all SEN students in the city's public schools, including kindergarten, elementary schools (stages I and II) and special education schools. The database contains the following indicators for SEN students: diagnostic reports, sociodemographic and socioeconomic indicators, school unit and use of educational, social and health services.

The study sample comprised the 1,202 SEN students recorded in the database who attended public schools, from a total of 59,344 students. However, only 792 of the 1,202 students had an established diagnosis. The average age of these 792 SEN students was 13 years old (SD = 6.59), 500 were male $(63.1 \%)$.

Table 1 shows the sample data according to sex, age range, distribution by educational levels and indicators of medication profile and use of educational support services and social indicators.

\section{RESULTS}

In order to present up-to-date data, the diagnostic reports of the 792 students were grouped according with the SEN categories as defined by Brazilian law ${ }^{9}$. We verified that $13.3 \%$ of the disorders were not part of this SEN categories but were classified as specific learning disorders and psychiatric disorders according to 5 th edition of the Diagnostic and Statistical Manual of Mental Disorders. Two specialists in developmental disorders made this grouping jointly.

From the diagnostic reports, it was possible to create six qualifying groups: (1) intellectual disability, comprising genetic syndromes and other conditions associated with intellectual disability; (2) sensory impairment, comprising visual impairment, hearing impairment, multiple sensory disabilities without intellectual disability or autism spectrum disorder; (3) physical disability, comprising cerebral paralysis, localized paralysis, non-progressive chronic encephalopathy without intellectual disability, isolated physical defects not related to the central nervous system or intellectual disability; (4) autism spectrum disorder, comprising global disorder/pervasive developmental disorder and Asperger's; (5) specific learning disorders, comprising dyslexia, dyscalculia or learning disorders; (6) other psychiatric disorders, comprising depression, anxiety, schizophrenia, disruptive behavior, impulse control and conduct disorders, and attention deficit/hyperactivity (Table 2).

\section{DISCUSSION}

It is notable, in Table 1 that a large proportion of SEN students show school delay, since $29.4 \%$ should have completed elementary school by 14 years of age. Benefits offered by the government can be used as indicators of poverty. In this study, $36 \%$ of families received food aid and $19.6 \%$ received a family allowance. Currently, approximately $25 \%$ of all Brazilian families receive a family allowance, with the highest concentration in the north-east ${ }^{10}$. As only those with per capita incomes of less than $\mathrm{R} \$ 70$ receive a family allowance, one can conclude that almost one in five students in this research are below the poverty line. Recent studies have pointed to the significant benefits of the family allowance program with regard to various aspects of child health, such as more frequent attendance of children at primary health care units to monitor development and for vaccination, as well as decreased mortality of children under five years of age as a result of poverty ${ }^{11,12}$. There are no specific data on the benefits of a family allowance for people with SEN, but a plausible hypothesis is that these children and adolescents are benefiting equally or even more than typical ones, as poverty adds to the particular challenges of disability or chronic health problems.

Our data shows in Table 2 that intellectual disability is the most frequent SEN condition in the studied public schools, followed by sensory disabilities, physical disability, 
Table 1. Characteristics of special educational needs students in a public educational system: sociodemographic profile, schooling, diagnosis and use of services ( $N=792)$.

\begin{tabular}{|c|c|c|}
\hline Characteristics & & $\begin{array}{c}\text { Total Sample } \\
\text { N (\%) }\end{array}$ \\
\hline \multirow[t]{2}{*}{ Sex } & Female & $292(36.9)$ \\
\hline & Male & $500(63.1)$ \\
\hline \multirow[t]{5}{*}{ Age range } & 0 - 3 years & $14(1.2)$ \\
\hline & $4-5$ years & $63(5.2)$ \\
\hline & $6-10$ years & $379(31.5)$ \\
\hline & 11 - 14 years & $393(32.7)$ \\
\hline & $\geq 15$ years & $353(29.4)$ \\
\hline \multirow[t]{3}{*}{ Use of medication } & Yes & $347(43.8)$ \\
\hline & No & $383(48.4)$ \\
\hline & No information & $62(7.8)$ \\
\hline \multirow[t]{4}{*}{ School type } & Day-care nursery & $12(1.5)$ \\
\hline & Kindergarten & $58(7.3)$ \\
\hline & Elementary school & $563(71.1)$ \\
\hline & Special education school & $159(20.1)$ \\
\hline \multirow[t]{3}{*}{$\begin{array}{l}\text { Specialized education } \\
\text { support service }\end{array}$} & Yes & $233(29.4)$ \\
\hline & No & $526(66.4)$ \\
\hline & No information & $33(4.2)$ \\
\hline \multirow[t]{3}{*}{ Family allowance } & Yes & $155(19.6)$ \\
\hline & No & $584(73.7)$ \\
\hline & No information & $53(6.7)$ \\
\hline \multirow[t]{3}{*}{ Food aid } & Yes & $285(36.0)$ \\
\hline & No & $457(57.7)$ \\
\hline & No information & $50(6.3)$ \\
\hline \multirow[t]{3}{*}{ Wheelchair user } & Yes & $50(6.3)$ \\
\hline & No & $711(89.8)$ \\
\hline & No information & $31(3.9)$ \\
\hline \multirow[t]{3}{*}{ Adapted transport } & Yes & $24(3.0)$ \\
\hline & No & $713(90.0)$ \\
\hline & No information & $55(6.9)$ \\
\hline \multirow[t]{3}{*}{ Use of diaper } & Yes & $100(12.6)$ \\
\hline & No & 670 (84.6) \\
\hline & No information & $22(2.8)$ \\
\hline
\end{tabular}

Table 2. Regrouped diagnosis of records of students with special education needs ( $N=792)$.

\begin{tabular}{lc}
\hline Diagnosis & $\mathrm{n}(\%)$ \\
\hline Intellectual Disability & $410(51.8)$ \\
\hline Sensory Impairment (Visual/Hearing/Multi) & $125(15.8)$ \\
\hline Physical Disability & $124(15.7)$ \\
Autism Spectrum Disorder & $28(3.5)$ \\
Specific Learning Disability & $14(1.8)$ \\
Other Psychiatric Disorder & $91(11.5)$ \\
\hline
\end{tabular}

psychiatric disorders, autism spectrum disorder and, finally, specific learning disorders. Considering the proportion of students with SEN in relation to the total number of students enrolled in the schools, it is possible to conclude that there is underdiagnosis of SEN cases, and consequently under-reporting of these cases to the education department. Taking autism spectrum disorder as an example, where the estimated prevalence is between 0.6 and $1 \%^{13,14}$, in this study only $0.05 \%$ of students were classified with this diagnosis.

The under-reporting of autism spectrum disorder found in our study (Table 2) makes us reflect on two problems: firstly, the probable negative effects arising from a lack of a diagnosis on development and behavior, as evidence-based practice recommends early intervention in autism spectrum disorder ${ }^{15,16,17}$ and secondly, that undiagnosed children are not receiving any specialized educational support. This creates a mismatch between the actual situation and the records of diagnostic reports that have been used in studies in Brazil, with examples of flawed or incomplete records or, in some cases, missing records ${ }^{18}$. Furthermore, when a child is enrolled in a regular school, the educational team may develop teaching methods that are not focussed on the needs of these students, accentuating learning difficulties and prejudicing social adaptation in general ${ }^{6}$. Curricular adaptations and appropriate management strategies are essential to support learning in autism spectrum disorder students. Evidence shows that most of them cannot learn by traditional methods because of the difficulty of responding to complex instructions and maintaining attention on several simultaneous stimuli presented during classes, due to multiple deficits in social cognition indicators, behavioral changes, cognitive deficits, such as in inhibitory control functions, and the presence of intellectual disability in approximately $70 \%$ of cases $^{19,20,21}$.

Diagnostic reports also shows that 105 students (13.3\% of those with SEN) are grouped as having a learning disability or other psychiatric disorder that is not legally recognized as SEN according to Brazilian law. The fact that there is such a high proportion of SEN students recorded as having learning/psychiatric disorders further strengthens the need to take steps to produce accurate diagnoses. This outcome raises the following considerations: a) it is probable that these learning/psychiatric diagnoses do not reflect the real primary condition, and it is the responsibility of the health services to provide a reliable diagnosis so that these students are included as SEN students; b) if this actually is the primary diagnosis of the student, we note an inappropriate use of SEN services in these cases.

This study also mapped aspects related to the use of social inclusion services and medication. The identified data show that, from a functional point of view, about $10 \%$ use a wheelchair, adapted transport or diapers. One interesting development is the registration and classification of various functional domains using the criteria of the International Classification of Functioning ${ }^{22}$. There have been some successful experiences in the Brazilian educational context ${ }^{23,24,25}$. As well, almost $50 \%$ of SEN students use medications regularly. 
One noteworthy item in Table 1 is the low percentage of SEN students who have access to specialized educational services or support. Approximately $67 \%$ do not use this type of service. An analysis comparing the diagnostic condition with the use of these services indicated that only $32 \%$ of students with intellectual disability, and $25 \%$ with autism spectrum disorder were using them. To provide comprehensive care to this population, pedagogical and educational measures, and adaptations to the curriculum (multilevel or overlapping curricula), as recommended in studies from other countries, should be made in the classroom ${ }^{6}$.
Although the present study brings contributions for the field, it has some limitations typical of studies based on secondary data, such as the reduced number of collected variables and absence of some relevant information, such as the diagnostic status of some of the sample.

In conclusion, these data suggest that there is a mismatch between the diagnostic records and the SEN condition legally recognized according to Brazilian law, in addition to the under-reporting and under specialized service use of students with disabilities.

\section{References}

1. Hubner LM, Feldman HM, Huffman LC. Parent-reported shared decision making: autism spectrum disorder and other neurodevelopmental disorders. J Dev Behav Pediatr. 2016;37(1):20-32. https://doi.org/10.1097/DBP.0000000000000242

2. Zablotsky B, Pringle BA, Colpe LJ, Kogan MD, Rice C, Blumberg SJ. Service and treatment use among children diagnosed with autism spectrum disorders. J Dev Behav Pediatr. 2015;36(2):98-105. https://doi.org/10.1097/DBP.0000000000000127

3. Vostanis P, Martin P, Davies R, De Francesco D, Jones M, Sweeting R et al. Development of a framework for prospective payment for child mental health services. J Health Serv Res Policy. 2015;20(4):202-9. https://doi.org/10.1177/1355819615580868

4. Brasil. Orientações para implementação da política de educação especial na perspectiva da educação inclusiva [cited 2017 Feb 22]. Available from: http://portal.mec.gov.br/index.php?option=com_ docman\&view=download\&alias=17237-secadi-documentosubsidiario-2015\&|temid $=30192$

5. American Psychiatric Association. Diagnostic and statistical manual of mental disorders. 5th ed. Porto Alegre:Artmed; 2014.

6. Reilly C. Behavioural phenotypes and special educational needs: is aetiology important in the classroom? J Intellect Disabil Res. 2012;56(10):929-46. https://doi.org/10.1111/j.1365-2788.2012.01542.x

7. Gomes CGS, Mendes, EG. [Inclusive schooling of students with autism in municipal education of Belo Horizonte]. Rev Bras Educ Espec. 2010;16(3):375-96. Portuguese. https://doi.org/10.1590/S1413-65382010000300005

8. Developmental Disabilities Monitoring Network Surveillance Year 2010 Principal Investigators. Prevalence of autism spectrum disorder among children aged 8 years: autism and developmental disabilities monitoring network, 11 sites, United States, 2010. MMWR Surveill Summ. 2014;63(Suppl 2):1-21.

9. Brasil. Decreto N0 7.611, de 17 de novembro de 2011. Dispõe sobre a educação especial, o atendimento educacional especializado e dá outras providências. Diário Oficial União. 2011 Nov 18.

10. Portal Brasil. Cidadania e Justiça. Bolsa Família beneficia mais de 13 milhoes de famílias de baixa renda. Brasília, DF; 2015 [cited 2017 Feb 22]. Available from: http://www.brasil.gov.br/ cidadania-e-justica/2015/04/bolsa-familia-beneficia-mais-de-13mi-familias-de-baixa-renda

11. Shei A, Costa F, Reis MG, Ko, Al. The impact of Brazil's Bolsa Familia conditional cash transfer program on children's health care utilization and health outcomes. BMC Int Health Hum Rights. 2014;14(14):10. https://doi.org/10.1186/1472-698X-14-10

12. Rasella D, Aquino R, Santos CAT, Paes-Sousa R, Barreto ML. Effect of a conditional cash transfer programme on childhood mortality: a nationwide analysis of Brazilian municipalities. Lancet. 2013;382(9886):57-64. https://doi.org/10.1016/S0140-6736(13)60715-1
13. Baxter AJ, Brugha TS, Erskine HE, Scheurer RW, Vos T, Scott JG. The epidemiology and global burden of autism spectrum disorders. Psychol Med. 2015;45(3):601-13. https://doi.org/10.1017/S003329171400172X

14. Kim, YS, Fombonne E, Koh YJ, Kim SJ, Cheon KA, Leventhal BL. A comparison of DSM-IV pervasive developmental disorder and DSM-5 autism spectrum disorder prevalence in an epidemiologic sample.J Am Acad Child Adolesc Psychiatry. 2013;53(5):500-8. https://doi.org/10.1016/j.jaac.2013.12.021

15. Zwaigenbaum L, Bauman ML, Stone WL, Yirmiya N, Estes A, Hansen RL et al. Early Identification of Autism Spectrum Disorder: Recommendations for Practice and Research. Pediatrics. 2015;136(Suppl 1):S10-40. https://doi.org/10.1542/peds.2014-3667C

16. Brentani H, Paula CS, Bordini D, Rolim D, Sato F, Portolese J et al. Autism spectrum disorders: An overview on diagnosis and treatment. Rev Bras Psiquiatr. 2013;35 Suppl 1:S62-72. https://doi.org/10.1590/1516-4446-2013-S104

17. Rogers SJ, Dawson G. Intervenção precoce em crianças com Autismo. Lisboa: Lidel; 2010.

18. Tramontina S, Martins S, Michalowskia MB, Ketzer CR, Eizirik $\mathrm{M}$, Biederman $\mathrm{J}$ et al. Estimated mental retardation and school dropout in a sample of students from state public schools in Porto Alegre, Brazil. Rev Bras Psiquiatr. 2002;24:177-81. https://doi.org/10.1590/S1516-44462002000400006

19. Teixeira. MCTV, Silva NA, Baraldi GS, Emerich DR, Milan E, Carreiro LR. Intervenções em sala de aula com alunos com Transtorno do Espectro Autista. In: Dias MN, Mecca TP, organizers. Contribuições da psicologia e neuropsicologia à intervenção no contexto escolar. São Paulo: Memnon; 2015. p. 249-55.

20. Jacobs DW, Richdale AL. Predicting literacy in children with a high-functioning autism spectrum disorder. Res Dev Disabil. 2013;34(8):2379-90. https://doi.org/10.1016/j.ridd.2013.04.007

21. Mucchetti CA. Adapted shared reading at school for minimally verbal students with autism. Autism. 2013;17(3):358-72. https://doi.org/10.1177/1362361312470495

22. Organização Mundial da Saúde. Classificação internacional de funcionalidade, incapacidade e saúde para crianças e jovens. São Paulo: EDUSP; 2011.

23. Miccas C, D’Antino MEF. Avaliação de funcionalidade em atividades e participação de alunos com deficiência intelectual: estudo-piloto para elaboração de protocolo escolar. Temas Desenvolv. 2011;18(102):82-9.

24. Miccas C, Vital MA, Lederman V, D’Antino MEF. Classificação internacional de funcionalidade, incapacidade e saúde e os transtornos do espectro do autismo. In: D’Antino, ME, Brunoni D, Schwartzman JS, editores. Contribuições para a inclusão escolar de alunos com necessidades especiais: estudos interdisciplinares em educação e saúde em alunos com transtornos do espectro do autismo no município de Barueri, SP. São Paulo: Memnon; 2015. p. 68-80.

25. Miccas C. Adaptação cultural para o Brasil da Matriz de Avaliação das Atividades e Participação para Autismo (MAAPA) [thesis]. São Paulo: Universidade Presbiteriana Mackenzie; 2015. 